\title{
1. Welfare Attitudes in Times of Crisis and Austerity
}

\author{
Bart Meuleman, Wim van Oorschot and \\ Tijs Laenen
}

\subsection{INTRODUCTION: WELFARE CHALLENGES, CHANGING DEBATES AND WELFARE REFORM}

As a modern social institution taking responsibility for the fair redistribution of life chances, the welfare state is regarded as a European invention, and the existence of an encompassing welfare state has often been depicted as one of the defining criteria of Europe. Notwithstanding this, the concept of the welfare state and its concrete manifestations in specific social policies has become substantially challenged in recent decades due to a number of major economic, social and political developments. First, as a result of an ongoing process of globalization, international economic competition has intensified, which threatens the redistributive capacity of national welfare states (Korpi and Palme, 2003). Globalization also implies growing migration flows into Europe, leading to increasing cultural and ethnic diversity, with possible negative consequences for the social legitimacy base of welfare provision (Kymlicka and Banting, 2006). Second, demographic ageing, new family arrangements and labour market flexibilization have resulted in increasingly precarious and insecure life courses, as well as the disturbance of social contracts between social classes and groups (Standing, 2011), thereby confronting many citizens and the welfare state institution with 'new social risks' associated with post-industrial society (Taylor-Gooby, 2004; Bonoli, 2005). Third, a double bind of rising expenditure on social (pension) benefits and (health) care combined with increased fiscal pressures has resulted in an era of relative austerity (Hemerijck, 2013). Fourth, the European Union is becoming a critical intervening level in domestic processes of welfare state change, leading to an era of semi-sovereign welfare states in which European welfare states become restrained in their national socioeconomic, labour market and social provision policies (Ferrera, 2003). However, the welfare 
state is not only challenged by structural factors and processes, increasingly it is subjected to more ideologically grounded accusations of undermining individual autonomy and responsibility, of damaging traditional social ties and of weakening private forms of solidarity and self-help. The idea of collective, public responsibility for the contingencies of modern life - which is at the base of the solidaristic welfare state 'European style' - is giving in to a perspective that emphasizes the value of individual responsibility and, related to this, of private and informal welfare arrangements (for example de Beer and Koster, 2009).

The longer-term structural and ideological challenges have been exacerbated by the shock of the banking crisis in 2008, which was quickly followed by an economic recession in 2009. This in turn triggered a longerlasting fiscal and debt crisis in many European states. As a reaction to these interconnected crises, governments in some European countries implemented far-reaching fiscal consolidation programmes, including significant welfare retrenchment and labour market reforms. Other countries launched general austerity programmes. In this same recent period, worldwide political instability and military conflicts have set off sizeable refugee and migration movements towards Europe, thereby putting additional strain on welfare systems. The combination of these challenges has resulted in a precarious political context, marked in many European welfare states by an intensification of critical social and political debates about the necessity and fairness of redistributive, solidaristic relationships that have been organized through existing welfare arrangements, or that - in the light of social and economic challenges - should be organized anew (Schubert et al., 2009). In many European countries, the debates have resulted in various policy reforms. For instance, the intense debate about pensions we see in most European countries is not only a manifestation of changing group interests as a result of population ageing, but also of changing views regarding the solidarity between generations (EU, 2004; Kohli, 2005). Typical pension policy reforms that have been implemented involve the retrenchment of early exit pre-pension schemes, the increase of statutory pension ages and a greater reliance on private pension arrangements (OECD, 2004). The greater ideological emphasis on individual responsibility translates into decreasing solidarity of the 'rich' with the 'poor', and is pivotal to many of the welfare retrenchment measures of the past decades, notably the increased role of means testing as an instrument of allocating social entitlements (Fraser et al., 2011). The EU-wide policy trend towards 'activation' - manifested for example in a general increase in work-record requirements for benefits, as well as an increase in job seeking obligations for unemployed people reflects a renewed positioning of ideas on the distribution of rights and obligations between the employed and the unemployed (Serrano Pascual and 
Magnusson, 2007). The debate about the integration of migrants in European societies, and about their access to social provisions, is affected to a large degree by ideas about their welfare deservingness (Kymlicka and Banting, 2006; van Oorschot, 2006), which is perceived as considerably lower than that of other needy groups in society (van Oorschot, 2006). Lastly, there is an ongoing supranational European debate, ignited substantially by the unequal degree to which the economic crisis has hit the different countries in Europe. This concerns the solidarity between Europeans, addressing the question of whether the re-distribution of welfare from richer to poorer European countries, for example in the form of a European minimum benefit scheme, would be necessary from the perspective of creating cross-European social cohesion, and whether it would be politically and economically feasible (Ferrera, 2003; Mau, 2005).

Amidst the social, economic and political turmoil of especially the past decade, and considering the intensified political debates and evolving policy reforms, it is important to have a broad and deep insight into the social legitimacy of European welfare states and their (reformed) policies. This social legitimacy, indicated by the degree to which the general public supports the welfare state and its provisions, is recognized as playing a role in the democratic politics of the welfare state. This is either as an ex-ante factor informing policymakers about the welfare preferences of citizens, to which they then can anticipate (see for example Brooks and Manza, 2007), or as an ex-post factor informing them about citizens' evaluations of policies, to which they can react with adaptations (see for example Kumlin and Stadelmann-Steffen, 2014). More recently, various volumes have addressed the social legitimacy of European welfare states by analysing and comparing the welfare attitudes of European citizens, mostly based on data from the first welfare attitudes module in the European Social Survey 2008 (ESS wave 4) (for example Ervasti et al., 2012; Svallfors, 2012; Kumlin and StadelmannSteffen, 2014; van Oorschot et al., 2017). However, most of these analyses are confined to a single year: 2008 for studies analysing the module mentioned. Given that the financial crisis of 2008-2009 and its aftermath of economic downturn intensified the structural, ideological and social pressures that were already put on the shoulders of the European welfare states, and as a result has led to an intensification of on-going reform processes, it has become pertinent to know how Europeans' welfare attitudes have developed subsequently. This important question can be addressed with the recent release of the data from the ESS 2016 repeat module on welfare attitudes (ESS wave 8), which thus allows for an over-time comparison of European welfare attitudes between 2008 and 2016.

This volume takes advantage of the availability of the two waves of the ESS and aims to shed light on the question of how public opinion on 
European welfare states and social policies has developed between 2008 (the year of the banking crisis, coinciding with the year in which the first welfare attitudes module of the ESS was fielded) and 2016 (the year in which the repeat module was fielded). To this end, all the chapters in this book compare data from these two ESS welfare attitudes modules. Further on, we will briefly introduce their contents, and explain which particular social issues and research questions they address. Before doing so, we would like to discuss the central findings of analyses of the 2008 data to set a frame of reference for what may be gained by comparing the data from 2008 and 2016.

\subsection{COMPARING EUROPEANS' WELFARE ATTITUDES IN 2008 AND 2016}

\subsubsection{A Multi-Dimensional Perspective on Welfare Attitudes}

Throughout the book we take a multi-dimensional perspective on the social legitimacy of the welfare state (in line with Svallfors, 1991; Sihvo and Uusitalo, 1995; van Oorschot and Meuleman, 2012; Roosma et al., 2013; Roosma, 2017). This means that we regard the welfare state as a multifaceted institution, and that each citizen may have different - either more positive or more negative - views of the various facets or dimensions. At the national level, this means that public support for the welfare state, or its social legitimacy, cannot be captured with a single measurement. The various dimensions of the welfare state can each have higher or lower degrees of perceived legitimacy. Figure 1.1 shows how we conceive the multidimensionality of the welfare state. The chapters in this volume each focus on attitudes to different dimensions, related to the specific research questions they address. This is made possible by the fact that the questions in the ESS welfare attitudes module reflect the various dimensions more or less closely.

Very briefly explained (in line with Roosma et al., 2013), Figure 1.1 identifies seven welfare state dimensions, the first being the welfare mix. This dimension recognizes that in addition to the state, there are other redistributive institutions, the roles of which - relative to that of the state and to each other - are important matters of debate and opinion: Should the state redistribute, or should we leave this up to the family, the market or private institutions such as for example the church? The second dimension, goals, focuses on the main redistributional aims of the state. This dimension relates to the two welfare state goals that have developed through democratization and industrialization: The goal to impose some form of social justice in 
which all people are considered to be of equal worth, and the goals of social security and protecting people against the rigidity of the market. Next, Figure 1.1 distinguishes a range and a degree dimension. Given that the welfare state redistributes to achieve its goals, these dimensions concern the questions of what areas of life and society the state should redistribute in (range), and how much redistribution there should be (degree). These are usually the core dimensions in welfare state attitudes research, since most opinion surveys include (only) questions specifically about them. The next dimension, redistribution, concerns the actual design of the redistribution process. This relates to issues such as: Who should benefit from the redistribution in different policy areas, who should contribute to it, and for what reasons and on what conditions? Who should carry the burdens of redistribution? What groups are deserving of what types of benefits, and under what conditions?

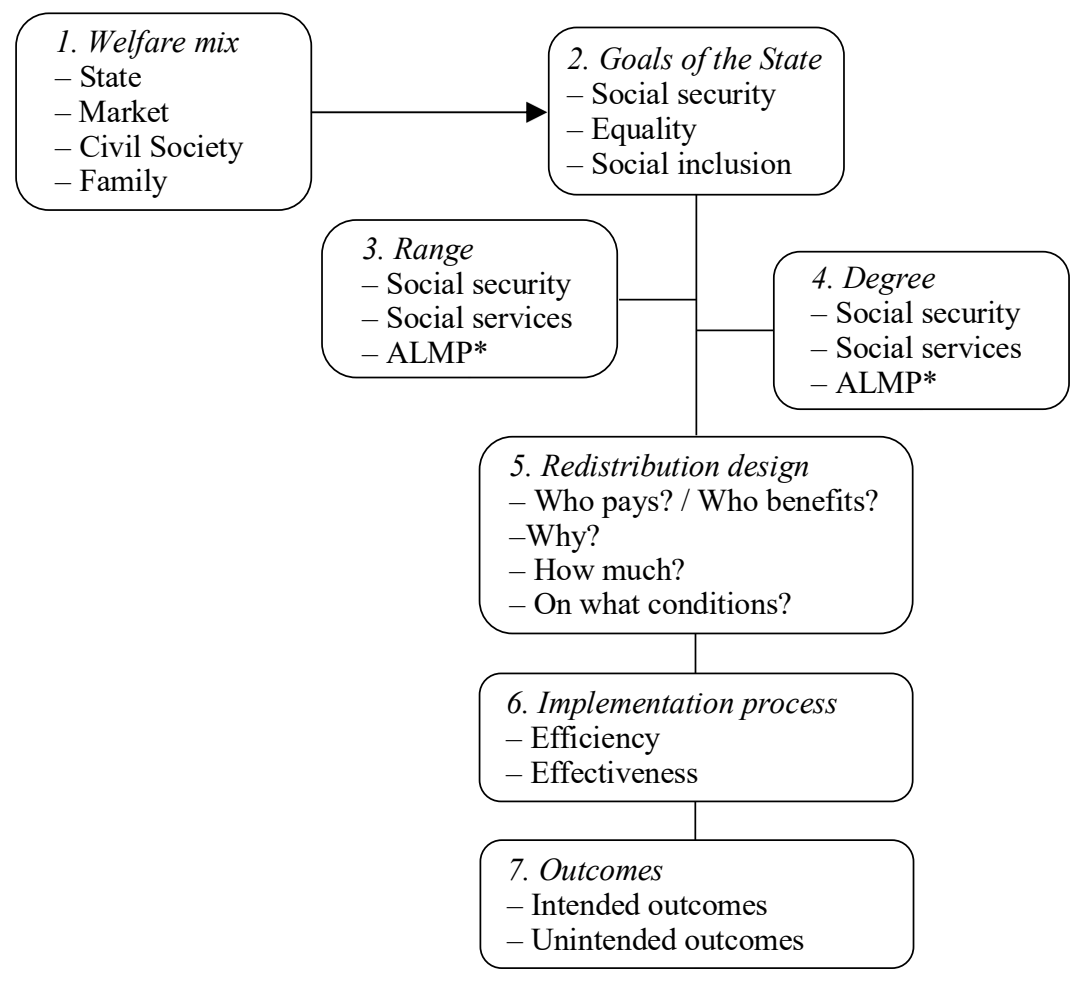

Note: $\quad *$ ALMP $=$ active labour market policy.

Source: Roosma et al., 2013.

Figure 1.1 Dimensions of the welfare state 
The implementation dimension refers to what the welfare state is actually doing. This has two sub-dimensions: efficiency and effectiveness. Efficiency considers questions such as: Are administrations and services avoiding wasting money? Are they delivering on time, and easy to understand? Are they accountable and accessible? Effectiveness pertains to whether benefits and services reach the legitimate beneficiaries and no others. That is, it is concerned with overuse (fraud and misuse) and underuse (non-take-up). Lastly, Figure 1.1 distinguishes an outcomes dimension, which is divided in two sub-dimensions: intended outcomes and unintended outcomes. On the one hand, intended outcomes can relate to the welfare state's goals: Are equality, social security and activation attained? Is inequality reduced and is social security provided? On the other hand, intended outcomes can relate to outcomes of the redistribution process: Are benefits generous enough and are services satisfactory? Unintended outcomes refer to the economic and moral consequences of the welfare state. The former relates to the financial burden of the welfare state on the government budget, and its consequences for tax levels and the economy. The latter concerns possible moral hazards. People can rely on the welfare state too much by shunning their own responsibility or becoming lazy or individualistic.

Having sketched out the multiple dimensions of the welfare state, we are now able to discuss welfare attitudes in 2008 as a frame of reference for the over-time comparisons that are central to this volume.

\subsubsection{Welfare Attitudes in 2008: Main Results from the First ESS Module}

The first ESS 2008 welfare attitudes module had a substantial impact in the field, because for the first time it offered a series of detailed measurements of attitudes towards a broad range of dimensions of the welfare state. Comparative surveys that existed at the time (such as the World Values Study, the International Social Survey Program and the International Social Justice Project) cover a broad range of countries with widely different cultural and historical traditions, and huge differences in institutional conditions. However, they were not explicitly designed to measure welfare attitudes, which implies that they contain only fairly broad and general items (mainly addressing attitudes to government responsibility for reducing income inequality and the provision of services). These surveys therefore do not fully capture the various welfare state dimensions, to which people have clearly different attitudes. It is true that existing national data sets often cover a much more specific range of topics, dealing with issues such as risk perception, trust in the welfare state, beliefs about sustainability, views about target groups and claimants, attitudes to financing and service delivery, and 
views about alternative welfare arrangements. However, only a few countries in Europe have held such national surveys, and their data can often not be compared across countries due to differences in data collection strategies, framing and question wording.

The 2008 ESS module changed this situation completely, making crossnational, comparative data about a range of welfare attitudes available for the first time. The analyses and studies it enabled have led to several crucial and innovative findings. For instance, while earlier welfare attitudes research was limited to relatively general measurements of support for the welfare state, and usually found wide popular support, the fine-grained measurements in the ESS module differentiate between various dimensions of welfare attitudes and allowed assessment of the multi-dimensionality of attitudes. This showed a less rosy picture of welfare support, since it was found that people might at the same time combine more positive and more critical welfare opinions (Roosma et al., 2013). In this respect, it is interesting that while welfare regime types differ across Europe, welfare attitudes do not closely follow Esping-Andersen's three worlds of welfare capitalism. Instead, in terms of welfare attitudes there seem to be two worlds: Northern and Western Europe, versus Eastern and Southern Europe. In the north and west, people generally endorse the principle of redistribution and welfare state responsibility for citizens' well-being, and they evaluate positively the way in which these principles are implemented. By comparison, people in the south and east also endorse the principles, but are much more critical about their practical implementation. In other words, they are strongly in favour of welfare provision by the state, but they are disappointed about what their states actually deliver (Roosma et al., 2013; Roosma et al., 2014b).

With regard to general criticisms of the (unintended) consequences of the welfare state, it was shown that Europeans do see problematic moral and economic consequences of welfare provision (for example it would make people less responsible for themselves and each other, and welfare would be bad for people's work ethic and for economic competitiveness). This neoconservative belief of a culture of dependency allegedly created by welfare states is a key factor shaping welfare attitudes, in particular in liberal welfare states where meritocratic attitudes are prevalent (Likki and Staerklé, 2015). However, Europeans see to a greater extent the social advantages of welfare provision (welfare reduces inequality, stimulates social order and leads to a better quality of life for many). Typically, in the most developed welfare states of Europe people are most critical about problematic consequences, but they also have a clearer view concerning the positive consequences (van Oorschot et al., 2012).

Generally, contextual factors have been shown to play a role in moulding people's welfare attitudes. Differences in the institutional welfare design of 
specific social policies affect specific attitudes regarding these policies, while economic circumstances in particular affect more general and abstract attitudes, as well as attitudes about the deservingness of welfare target groups. The better the economy fares, the more welfare minded and solidaristic Europeans tend to be (van Oorschot and Meuleman, 2012; 2014). It has also been shown that people's support for specific welfare services and benefits strongly depends on their beliefs about the deservingness of the target groups. Various deservingness criteria play a role in this, especially identity, control and reciprocity (van Oorschot, 2000; van Oorschot and Meuleman, 2014). Related to deservingness, the overuse of benefits and services (fraud and misuse) is seen as an important problem by large sections of European populations, but no less so is underuse (non-take-up). The latter is especially prevalent in Eastern and Southern Europe, which is another sign that the public in less-developed European welfare states are disappointed with what their welfare states deliver (Roosma et al., 2014a). Generally, migrants are seen as least deserving of welfare compared with other social groups, and it has been found that there is welfare chauvinism among a considerable proportion of the European public. However, there is no clear sign that cross-national differences in welfare chauvinism are related to a 'welfare magnet effect'; that is, to institutional design or the degree of social spending. The economic context and degree of income inequality seem to be more important (Reeskens and van Oorschot, 2012; van der Waal et al., 2013; Mewes and Mau, 2012). It has also been shown that ethnic prejudice is associated with negative attitudes towards welfare provision in Western European contexts with extensive welfare states, but not in Eastern and Central European contexts where the immigration-welfare nexus is less politically prominent (Staerklé et al., 2012).

With regard to the factors that directly affect people's welfare attitudes, it has been found that people's personal stake in welfare provision (related to their age, household type, educational level, profession, income level, perceived social insecurity and such like) has expected effects on their welfare attitudes, but their ideological position (values, beliefs and target group images) often has a stronger influence. That is, European welfare attitudes seem to be shaped more by people's ideas than by their self-interest (Roosma et al., 2013; van Oorschot and Meuleman, 2012). On the other hand, there are sizeable differences in class effects on welfare attitudes between European countries and types of welfare state, for which no successful explanations have as yet been found (Svallfors, 2012). Lastly, studies have shown that people's perceptions and evaluations of their welfare state's performance influence other important aspects of their general outlook on political and social life, such as their trust in political institutions (Kumlin 
and Stadelmann-Steffen, 2014), and their perceived employment and income (in)security (Chung and Mau, 2014).

\subsubsection{Opportunities Offered by the 2008-2016 Comparison}

Most generally, comparison of data from the two ESS modules allows us to detect and analyse changes in attitudes and their cross-national and crossindividual variation, as well as changes in relationships with determining factors at the individual and the contextual level. Such over-time comparisons are especially relevant now that Europe is experiencing the consequences of one of its most severe economic crises. By coincidence, the 2008 welfare attitudes module was fielded precisely when the 2008 financial crisis was about to unfold. The fieldwork began in seven countries (Denmark, Germany, Israel, the Netherlands, Norway Spain and Switzerland) in the weeks before 15 September 2008, the day the global crisis was triggered by the bankruptcy of Lehman Brothers. Cyprus, Finland, France, Portugal, Slovenia, Sweden and the UK started data collection between the second half of September and the end of October, which was the period when the financial crisis fully hit the European continent. Fieldwork in Belgium, Croatia, Estonia, Poland, Romania, Russia, Slovakia and Turkey started shortly after (November or December), and in 2009 for the remaining countries. While this specific timing of events might have been considered somewhat unlucky at the time, we are now convinced that it has resulted in a unique opportunity for welfare attitudes research. As explained, over the past ten years, Europe has gone through three interconnected crises: a banking crisis in 2008 , followed by an economic recession in 2009 , in turn triggering a fiscal crisis in different nations. In the aftermath of the fiscal crisis, Greece - together with Ireland, Portugal and Spain - implemented impressive fiscal consolidation programmes, including significant welfare retrenchment and labour market reform. In addition, conservative governments in Germany, France, Italy, the UK and the Netherlands launched austerity programmes. This profound multi-layered economic crisis can be seen as a natural experiment: An exogenous shock - namely plummeting economic growth and massive unemployment, with a variety of policy responses and steeply increasing economic insecurity as a consequence - was administered to European countries that are characterized by very different institutional setups and social realities. Although the intensity of the shock differed between European countries, in most nations the current crisis has cut much deeper than usual downward business cycles, and could have initiated a qualitatively different dynamic in the development of welfare attitudes.

These exceptional circumstances make it possible for the first time to study the attitudinal consequences of a deep economic downturn, while 
circumventing the problem of confusion between economic conditions and other contextual variables that limits the analytical possibilities of crossnational, one-off, single year measurements. For the 'natural experiment' design to function optimally, the second measurement of welfare attitudes (the post-test, so to speak) should ideally be carried out no sooner or later than when the impact of economic change on public opinion had sufficient time to materialize. While the financial crisis began several years ago, and was relatively quickly under control (for the time being at least), the damage to the real economy (economic production, the labour market and consumer demand) took years to reveal its full extent. Although initially there was economic recovery, the Covid-19 pandemic (that is raging through the world while this volume is being finalized) is now plunging Europe into a new episode of economic crisis. Furthermore, the crisis has prompted political leaders to take action, and as explained above, has made socioeconomic issues, welfare policies and the well-being, precariousness and deservingness of various groups of citizens highly salient topics in political discourse. In our view, the effects of the welfare policy reforms resulting from this discourse are only now becoming clear.

All the chapters analyse in greater detail the relationships between welfare attitudes and the national contexts in which people live. As mentioned, findings from the ESS 2008 data showed important contextual effects for welfare attitudes. The new data allows for the variation in context measurements to be increased by combining the 2008 and 2016 rounds, a procedure that gives more information about, and better tests of, context effects than was possible with only the 2008 data. While levels of institutional, cultural, economic and political factors have been analysed with the data from the first module (for example van Oorschot and Meuleman, 2014), the new data allows better testing of the effects of factors that have a more volatile nature, such as economic conditions, unemployment figures, welfare spending and institutional welfare design. In this way, the chapters allow us to substantially extend the knowledge about feedback effects on welfare attitudes (Kumlin and Stadelmann-Steffen, 2014).

It should be noted, however, that we are careful not to suggest that general or major attitude shifts are definitely to be expected. That is, the (relatively few) existing longitudinal studies in the field tend to find that opinions remain remarkably stable over time (Ringen, 1987; Borre and Scarbrough, 1995; Brooks and Manza, 2007), accordingly suggesting that the welfare state remains highly popular regardless of economic and political circumstances. Nevertheless, it should also be noted that these studies have various shortcomings. Most of them are national analyses and thus uninformative about welfare attitude change in Europe as a whole. They are also limited in their measurements of welfare attitudes, focusing on the 
preferred responsibilities of the government for the reduction of income inequality and the provision of specific services. These items refer to general principles that people readily agree with. As explained above, a key finding from the first module was that the welfare state has various other dimensions towards which people have specific attitudes. Typically, one of the main findings from the 2008 data was that there are important differences between what people would like to have from the welfare state and what they feel it is actually delivering. Nevertheless, comparing the 2008 and 2016 data potentially contributes significantly to our knowledge about welfare attitude change in European countries, as although national longitudinal surveys show considerable overall stability with regard to the general principles and aims of the welfare state, they also tend to find strong fluctuations concerning attitudes towards particular policies, practices and welfare target groups (Raven, 2012; Duffy et al., 2013; Jeene et al., 2013). In addition, relative stability at the surface (at the aggregate level of a country's public opinion) does not mean that nothing has changed. For example underlying structural conflicts between groups might be changing due to increased competition for scarce resources. Apart from general levels of attitudes, the effects of people's socioeconomic and ideological positions on their attitudes may change.

Hence, comparing attitudes between the two time periods offers a major opportunity to address the general question of how the welfare attitudes of Europeans have developed in times of crisis and austerity.

\subsection{CHANGE OR CONTINUITY? A PREVIEW OF CHAPTERS}

The chapters in this book are organized around three of the main findings of the 2008 module. The chapters in Part II focus on the general finding that welfare attitudes are multi-dimensional, in the sense that what matters in terms of the social legitimacy of the welfare state is not only what people would prefer the welfare state to do for them (which, as already explained, was mostly the idea before the ESS data made more detailed questions possible), but also how they perceive what the welfare state is actually doing. Individuals may combine support for what the welfare state should do, with critical beliefs and evaluations about what it actually is doing (Roosma, 2017). General questions addressed by the chapters are accordingly: Do we face increased general disappointment about what welfare states actually deliver, given that retrenchment is a general tendency in welfare reform? Or is there increasing support for the welfare state as a reaction to the increased socioeconomic uncertainty in many countries? How has the balance between 
criticism and support developed over time in Europe? Or is attitude change or continuity country-specific, reflecting differences in for example the degree to which the national economy was affected by the financial crisis, or in the levels and types of social policy reforms?

The chapter by Meuleman and Delespaul focuses on how people combine both critical and more-positive attitudes towards the welfare state. It is based on the premise that citizens' perceptions of the consequences of the welfare state are indeed complex and nuanced. On the one hand, the 2008 data evidenced that the critical view that the welfare state produces unintended economic and moral consequences was relatively widespread. Yet on the other hand, the European public was also convinced of the positive social consequences of welfare provision, and perceptions of these positive consequences outweighed the criticism about economic and moral aspects. There are several reasons to expect that the financial crisis affected perceived welfare consequences in several ways. The economic downturn caused unemployment rates to go up across Europe, but in some countries more notably than in others. Furthermore, the economic crisis has elicited varied policy responses: notably austerity measures. According to previous research (van Oorschot et al., 2012), these contextual factors have the power to affect popular perceptions of welfare consequences. High unemployment rates tend to stimulate concerns about the negative impact of welfare redistribution on economic performance. Welfare generosity, conversely, seems to reinforce positive social as well as negative moral and economic perceptions. Therefore, the context of crisis could have stirred up welfare criticism and eroded positive appraisals of the welfare state. To test these expectations, the chapter studies how perceptions of economic, moral and social consequences changed between 2008 and 2016. In addition to mapping aggregate change, it also analyses how individual as well as contextual characteristics affect the relevant perceptions.

The chapter by Roosma starts from the finding in the 2008 ESS that the weakest spot of the welfare state's social legitimacy was the high perceived levels of abuse and underuse of welfare benefits. In all European welfare states, citizens on average had the strong impression that many people obtain benefits they are not entitled to, but at the same time that many others get fewer benefits than they are entitled to (Roosma et al., 2014a). Although levels were generally high, there was also ample variation between European countries. After the shock of 2008 and its aftermath, European governments turned to various measures to address the impact of rising unemployment levels and falling economic growth figures. Some countries utilized stricter entitlements for social benefits and services, others limited social spending. One might expect that these changing macro level conditions altered the two most critical attitudes towards the welfare state. Have the so-called weakest 
links of welfare state legitimacy been further weakened? And if so, what does this imply for the social legitimacy and future of the welfare state? This chapter accordingly examines whether or not perceived abuse and underuse of welfare benefits have changed in contexts of altering economic and institutional conditions in Europe.

The chapter by Staerklé, Gale and Politi explicitly focuses on people's perceptions of the possible negative consequences of welfare provision - in particular, perceptions of welfare dependency - and how these affect their support for the welfare state. The chapter starts off from the observation that the most significant effect of the 2008 crisis has been the widespread implementation of austerity politics. These have had the greatest impact on the most vulnerable segments of national populations, especially in Southern Europe. The chapter examines how these developments have affected social cohesion beliefs (social distrust and institutional dissatisfaction), and critical beliefs about welfare intervention (welfare dependency) and welfare support across four European countries: two badly affected by the crisis, Ireland and Spain, and two relatively spared by it, Germany and Sweden. The chapter tests a theoretical model that suggests perceived material vulnerability leads to changes in the ways people conceive of the social bond. The main question is whether increased vulnerability leads to a breakdown of perceived social cohesion and thus to distrust in fellow citizens. These social cohesion beliefs may in turn shape critical beliefs about welfare dependency (whether social benefits make people lazy, less caring and passive in terms of job seeking), which in turn may determine whether people ultimately support or oppose social government intervention.

The three chapters presented thus far mainly focus on the 'is' dimension of welfare legitimacy (what people perceive that their welfare state is actually doing or producing). By contrast, the next chapter by Gugushvili and van Oorschot addresses the 'should' dimension, by analysing public preferences for government's responsibility in providing welfare for citizens. The chapter extends the usual geographical scope by focusing on change and continuity in welfare attitudes in Russia, although compared with general tendencies in European countries. Unlike European countries, Russia has suffered from a protracted crisis since 2014, and it was not until 2017 that it recorded a modest growth (Rosstat, 2018a, 2018b). Thus, while the effects of the 2008 crisis on welfare opinions may have already softened and returned to precrisis levels in European countries, the memories of the recession will still be fresher in Russian respondents' minds, allowing us to compare opinions right at the beginning and at the end of recession. On the other hand, Russia shares many similarities with European countries. It is perhaps one of the best examples of a non-OECD country with a long-established and relatively extensive social protection system. Russia has also been subjected to long 
and short-term demographic and economic pressures similar to those in the European welfare states. Further, previous research has shown that while Russians have higher welfare preferences and are less satisfied with what their government delivers compared with Europeans, in general, their welfare opinions in 2008 were largely compatible with those expressed by the Southern and Eastern European public (van Oorschot and Gugushvili, 2019). Therefore, finding similar or divergent patterns of opinion change in Russia can shed light on the extent to which the changes in welfare attitudes observed in European countries are unique, or reflect a general trend in similar institutional and attitudinal contexts.

The chapter by Ervasti addresses how support for the welfare state is affected by a particular cultural factor, people's religious orientations, and how the relationship between the two has changed over time in Europe. Although religiosity is often neglected as a determinant of welfare attitudes, there are obvious historical reasons for taking it into account. As it has been shown that the European welfare state has taken characteristically different forms according to religious variation (for example van Kersbergen, 1995; Manow, 2002), this chapter sets out to see whether religion-based differences in welfare attitudes can be found at the individual level, in addition to the country level. As has been well documented in recent literature, a marked change has taken place in the religious life of Europeans during recent decades. The main trend has been secularization, as notable sections of European populations have dropped out of religious affiliations and became estranged from all religious beliefs and behaviour. However, at the same time there are also slight tendencies towards increasing religious pluralism due to increasing immigration and, to a lesser degree, due to an increasing interest in new forms of religiosity. Data from the ESS from 2002 to 2016 is analysed to find out what repercussions the religious change has brought to the social and political values of Europeans. The leading questions are whether or not individuals' preferences about welfare policies depend on their personal religious commitment, which direction the relationship takes (is the religiosity of citizens supportive of welfare legitimacy, or does it detract from it) and has the impact of religiosity on welfare attitudes remained stable or is it gradually weakening or strengthening?

The chapters in Part III focus on the main finding in the 2008 data that the legitimacy of welfare provisions often strongly depends on the target groups that they address, which can be seen as an important corroboration of the central thesis of welfare deservingness theory (van Oorschot, 2006; van Oorschot et al., 2017; Laenen, 2020). The general questions addressed by the chapters concern whether we can witness changes or continuity in popular deservingness with and solidarity towards specific target groups, in particular the unemployed, elderly people and migrants. For example has there been a 
general increase in deservingness and solidarity given that economic hardship has risen among many target groups? Or do we see a general decrease, when for example greater socioeconomic insecurity would translate into increased concern about people's own living standard? Alternatively, are changes in solidarity target-group specific, expressing a form of 'deservingness competition' fuelled by political claims of unavoidable austerity? For instance, does the European public target solidarity more strongly towards the elderly as a traditionally deserving group, while becoming more conditional with regard to the unemployed and migrants? Such changing patterns of deservingness and solidarity might also be country specific, depending for example on actual developments in unemployment, on the degree of population ageing, on shifts in migration, on trends in income inequality and on the types and extent of welfare reforms.

The chapter by Laenen focuses on the welfare target group of the unemployed. It starts out from the common assumption that the institutional design of different welfare policies plays a crucial role in shaping popular deservingness perceptions towards their recipients (Laenen, 2020). First, the chapter explores how Europeans evaluate the unemployed in terms of their material needs and willingness to work, and how (or if) these evaluations changed between 2008 and 2016. The chapter subsequently examines how the degree of selectivity, generosity and conditionality of unemployment policies feed back into such deservingness perceptions, while also taking the larger economic macro context into account. The final step comprises an analysis of the impact of popular deservingness perceptions on public support for government-provided unemployment protection, net of a broader range of people's social-structural characteristics (for example their age) and ideological beliefs (for example their left-right political position). The basic idea behind the chapter is that changes in policy design characteristics can have (positive or negative) consequences for the ways in which Europeans perceive the unemployed, and consequently support the provision of unemployment benefits. Accordingly, popular welfare deservingness is understood as a mediating factor between welfare policies and their public support.

The chapter by Ebbinghaus and Naumann focuses on the welfare target group of the elderly, people's evaluations of and preference for pension provision, and how these might be influenced by significant ongoing pension reforms, such as increases in the retirement age, shifts towards private funding and recalibrated public pension benefits. Since politicians' room for manoeuvre to enact reforms is partly shaped and sometimes restricted by public opinion, the chapter explores public attitudes towards retirement income for the elderly and how these attitudes changed across 17 European countries between 2008 and 2016. To better understand how pension reform 
affects individual pension reform preferences, the chapter focuses first on subjective perceptions of these trends. It argues that changes in subjective performance evaluations are a prerequisite for individual attitude change concerning reform preferences. Therefore, the chapter explores how the evaluation of pensioners' living standards has changed over time. In a second step, the analysis examines whether changes in the subjective evaluation of pension income are related to altered preferences concerning pension reform. Do people continue to see the government as being responsible for the elderly? Further, do people's preferences vary in line with the (actual and perceived) standard of living of pensioners? Lastly, this chapter explores intergenerational solidarity; that is, the extent to which the attitudes of different cohorts have changed. Are there differences between younger and older people in perceiving living standards of the elderly as good or bad? Also, is there a generational conflict about who should be responsible for the elderly?

The chapter by Eger, Larsen and Mewes focuses on solidarity with the welfare target group of migrants. More specifically, it investigates whether the so-called 'migration crisis' of 2015 is associated with a change in welfare nationalist attitudes across 19 European countries. Often referred to as welfare chauvinism, welfare nationalism is also considered here as a system of social protection for those who belong to the ethnically defined community and who have contributed to it. Meta studies of the empirical literature on attitudes towards immigrants indicate that the relationship between public opinion and the actual levels of immigration is less than straightforward. Cross-national research has not found a specific direct relationship between welfare nationalism and the proportion of foreigners in a country's population. Nevertheless, one could argue that a dramatic, highly visible situation - such as the one that played out in 2015 - has the potential to change public opinion. This chapter asks first whether the highly visible 'migration crisis' is associated with a shift in welfare nationalist attitudes among Europeans. In a technical sense, the 'crisis' is treated as a natural experiment that allows us to investigate how a salient event affects popular attitudes towards granting social rights to immigrants. Does welfare nationalism increase or decrease, or do attitudes become more polarized? The chapter then goes on to investigate whether certain contextual changes, such as the political salience of the immigration issue, the presence of inclusive immigrant integration policies, the proportion of foreign-born and asylum seekers in the population, and economic conditions help to explain withincountry changes in support for the inclusion or exclusion of 'newcomers'.

The chapters in Part IV focus on the main finding in the 2008 data that (perceptions of) prevailing welfare provisions can influence other important aspects of people's outlook on economic and social life. 
The chapter by de Blok, Haugsgjerd and Kumlin studies public evaluations of the performance of welfare state policies, with a particular focus on how such evaluations impact on 'political trust'; that is, generalized confidence in democratic institutions. More specifically, it examines whether performance dissatisfaction increased between 2008 and 2016, given the welfare retrenchment reactions of several governments in Europe. Furthermore, it asks whether the negative effects of dissatisfaction on political trust have become stronger. With regard to both questions, the chapter analyses whether changes are more pronounced in countries and at time points more strongly exposed to the economic crises and related austerity policies. With regard to time, the particular question addressed is: In the time period studied, when exactly would any increases in levels and effects of welfare performance dissatisfaction be likely to occur? This question is situated in the context of the European experience in 2008-2016, a period with a financial crisis that carried over into consequences for the real economy. This was followed later by the government debt crises in the euro areas, while austerity policies with consequences for European welfare states were only implemented in most countries after 2010 (Armingeon, 2013; Hemerijck, 2013).

The chapter by Chung aims to replicate a study using the 2008 ESS data that examined whether it is market forces (in particular the state of the economy) or institutional arrangements (unemployment benefits and active labour market policies) that matter more in explaining cross-national variation in subjective employment insecurity across Europe. The previous study showed that for the early stages of the 2008 financial crisis, such variation was mainly driven by economic factors (higher subjective insecurity in worse economic circumstances), while differences in institutional arrangements regarding unemployment had little impact (Chung and van Oorschot, 2011). However, Europe has recovered from the crisis to a degree, with generally lower levels of unemployment and improved GDP growth rates. Therefore, the aim of the chapter is to determine whether market forces were still more influential in explaining the level of perceived insecurity in 2016-2017, eight years after the crisis, or whether welfare state institutions can now better explain the cross-country variation.

\section{REFERENCES}

Armingeon, Klaus (2013), 'Breaking with the past? Why the global financial crisis led to austerity policies but not to modernization of the welfare state, in C. Pierson, F. Castles and I. Naumann (eds), The welfare state reader, Oxford: Polity, pp. 214 26. 
Bonoli, G. (2005), 'The politics of the social policies: providing coverage against new social risks in mature welfare states', Policy and Politics, 33 (3), 431-49.

Borre, O. and E. Scarbrough (eds) (1995), The scope of government, Oxford: Oxford University Press.

Brooks, C. and J. Manza (2007), Why welfare states persist, Chicago: Chicago University Press.

Chung, H. and W. van Oorschot (2011), 'Institutions versus market forces: explaining the employment insecurity of European individuals during (the beginning of) the financial crisis', Journal of European Social Policy, 21 (4), 287-301.

Chung, H. and S. Mau (2014), 'Introduction to special issue: subjective insecurity and the role of institutions', Journal of European Social Policy, 24 (4), 303-18.

de Beer, P. and F. Koster (2009), Sticking together or falling apart? Solidarity in an age of individualization and globalization, Amsterdam: Amsterdam University Press.

Duffy, B., S. Hall, D. O'Leary and S. Pope (2013), Generation strains, London: DEMOS.

Ervasti, H., J. Goul Andersen, T. Fridberg and K. Ringdal (eds) (2012), The future of the welfare state: social policy attitudes and social capital in Europe, Cheltenham, UK and Northampton, MA, USA: Edward Elgar Publishing.

EU (2004), The future of pension systems, Brussels: European Commission.

Ferrera, M. (2003), 'European integration and national social citizenship: changing boundaries, new structuring?', Comparative Political Studies, 36 (6), 611-52.

Fraser, N., R. Gutierrez and R. Pena-Casas (eds) (2011), Working poverty in Europe: a comparative approach, Houndmills: Palgrave Macmillan.

Hemerijck, A. (2013), Changing welfare states, Oxford: Oxford University Press.

Jeene, M., W. van Oorschot and W. Uunk (2013), 'The dynamics of welfare opinions in changing economic, institutional and political contexts: an empirical analysis of Dutch deservingness opinions, 1975-2006', Social Indicators Research, 115 (2), 731-49.

Kohli, M. (2005), 'Generational changes and generational equity', in M. Johnson, V. Bengtson, P. Coleman and T. Kirkwood (eds), The Cambridge handbook of age and ageing, Cambridge: Cambridge University Press.

Korpi, W. and J. Palme (2003), 'New politics and class politics in the context of austerity and globalization: welfare state regress in 18 countries, 1975-95', American Political Science Review, 97 (3), 425-46.

Kumlin, S. and I. Stadelmann-Steffen (2014), How welfare states shape the democratic public: policy feedback, participation, voting, and attitudes, Cheltenham, UK and Northampton, MA, USA: Edward Elgar Publishing.

Kymlicka, W. and K. Banting (2006), 'Immigration, multiculturalism and the welfare state', Ethics and International Affairs, 20 (3), 281-304.

Laenen, T. (2020), Welfare deservingness and welfare policy: popular deservingness opinions and their interaction with welfare state policies, Cheltenham, UK and Northampton, MA, USA: Edward Elgar Publishing.

Likki, T. and C. Staerklé (2015), 'Welfare support in Europe: interplay of dependency culture beliefs and meritocratic contexts', International Journal of Public Opinion Research, 27 (1), 138-53.

Manow, P. (2002), 'The good, the bad, and the ugly: Esping-Andersen's SozialstaatsTypologie und die konfessionellen Wurzeln des westlichen Wohlfahrtsstaats', Koelner Zeitschrift fuer Soziologie und Sozialpsychologie, 54 (2), 203-25.

Mau, S. (2005), 'Democratic demand for a social Europe? Preferences of the European citizenry', International Journal of Social Welfare, 14 (2), 76-85. 
Mewes, J. and S. Mau (2012), 'Unraveling working class welfare chauvinism', in S. Svallfors (ed.), Contested welfare states: welfare attitudes in Europe and beyond, Stanford: Stanford University Press, pp. 119-57.

OECD (2004), Reforming public pensions: sharing the experiences of transition and OECD countries, Paris: Organisation for Economic Co-operation and Development.

Raven, J. (2012), Popular support for welfare state reforms: on welfare state preferences and welfare state reforms in the Netherlands, $\mathrm{PhD}$ thesis, Rotterdam: Erasmus University, accessed 11 November 2019 at http:/hdl.handle.net/ 1765/32005.

Reeskens, T. and W. van Oorschot (2012), 'Disentangling the "new liberal dilemma": on the relation between general welfare redistribution preferences and welfare chauvinism', International Journal of Comparative Sociology, 53 (2), 120-39.

Ringen, S. (1987), The possibility of politics: a study in the political economy of the welfare state, Oxford: Clarendon Press.

Roosma, F., J. Gelissen and W. van Oorschot (2013), 'The multidimensionality of welfare state attitudes: a European cross-national study', Social Indicators Research, 113 (1), 235-55.

Roosma, F., W. van Oorschot and J. Gelissen (2014a), 'Perceptions of mistargeting of social security benefits in European countries', Bulletin Luxembourgeois des Questions Sociales, 30, 21-46.

Roosma, F., W. van Oorschot and J. Gelissen (2014b), 'The preferred role and perceived performance of the welfare state: European welfare attitudes from a multidimensional perspective', Social Science Research, 44 (1), 200-210.

Roosma, F. (2017), 'A multidimensional perspective on the social legitimacy of welfare states in Europe', PhD thesis, Tilburg: Tilburg University.

Rosstat (2018a), GDP of Russian Federation, accessed 8 March 2018 at http://www.gks.ru/free_doc/new_site/vvp/vvp-god/tab2.htm.

Rosstat (2018b), Russia in figures, accessed 9 March 2018 at http://www. gks.ru/wps /wcm/connect/rosstat_main/rosstat/en/figures/population/.

Schubert, K., S. Hegelich and U. Bazant (2009), The handbook of European welfare systems, London: Routledge.

Serrano Pascual, A. and L. Magnusson (eds) (2007), Reshaping welfare states and activation regimes in Europe, Oxford: Peter Lang International Academic Publishers.

Sihvo, T. and H. Uusitalo (1995), 'Attitudes towards the welfare state have several dimensions', Scandinavian Journal of Social Welfare, 4 (4), 215-23.

Staerklé, C., T. Likki and R. Scheidegger (2012), 'A normative approach to welfare attitudes', in S. Svallfors (ed.), Contested welfare states: welfare attitudes in Europe and beyond, Stanford: Stanford University Press, pp. 81-118.

Standing, G. (2011), The precariat: the new dangerous class, London: Bloomsbury Academic.

Svallfors, S. (1991), 'The politics of welfare policy in Sweden: structural determinants and attitudinal cleavages', British Journal of Sociology, 42 (4), 60934.

Svallfors, S. (ed.) (2012), Contested welfare states: welfare attitudes in Europe and beyond, Stanford: Stanford University Press.

Taylor-Gooby, P. (ed.) (2004), New risk, new welfare: The transformation of the European welfare state, Oxford: Oxford University Press. 
van der Waal, J., W. de Koster and W. van Oorschot (2013), 'Three worlds of welfare chauvinism? How welfare regimes affect support for distributing welfare to immigrants in Europe', Journal of Comparative Policy Analysis, 15 (2), 164-81.

van Kersbergen, K. (1995), Social capitalism: A study of Christian democracy and the welfare state, London, Routledge.

van Oorschot, W. (2000). 'Who should get what, and why? On deservingness criteria and the conditionality of solidarity among the public', Policy and Politics, 28 (1), $31-48$.

van Oorschot, W. (2006), 'Making the difference in social Europe: deservingness perceptions among citizens of European welfare states', Journal of European Social Policy, 16 (1), 23-42.

van Oorschot, W., T. Reeskens and B. Meuleman (2012), 'Popular perceptions of welfare state consequences. A multi/level, cross/national analysis of 25 European countries', Journal of European Social Policy, 22 (2), 181-97.

van Oorschot, W. and B. Meuleman (2012), 'Does popular support for welfare states depend on their outcomes?', in S. Svallfors (ed.), Contested welfare states: welfare opinions in Europe and beyond, Stanford: Stanford University Press, pp. 25-57.

van Oorschot, W. and B. Meuleman (2014), 'Popular deservingness of the unemployed in the context of welfare state policies, economic conditions and cultural climate', in S. Kumlin and I. Stadelmann-Steffen (eds), How welfare states shape the democratic public: policy feedback, participation, voting, and attitudes, Cheltenham, UK and Northampton, MA, USA: Edward Elgar Publishing, pp. 244-68

van Oorschot, W., F. Roosma, B. Meuleman and T. Reeskens (eds) (2017), The social legitimacy of targeted welfare: attitudes towards welfare deservingness, Cheltenham, UK and Northampton, MA, USA: Edward Elgar Publishing.

van Oorschot, W. and D. Gugushvili (2019), Retrenched, but still desired? Perceptions regarding the social legitimacy of the welfare state in Russia compared with EU Countries, Europe-Asia Studies, 71 (3), 345-64. 